\title{
Mers-CoV and Zika Virus
}

\begin{abstract}
Chapter 6 analyses the recent emergence of Mers-CoV and the spread of Zika virus around the globe. With a glace into the future, especially with regard to emerging infectious diseases (EID), it explores the most important indicators of such emergence and spread, asking which local, national, and international characteristics come to the fore to heighten or mitigate such threats. It further initially evaluates how these might interact with accelerators such as climate change and migration, exploring in particular the allocation of health rights and responsibilities across borders. Between the timelines of response and the anticipation of new outbreaks, the chapter offers some pointers on what decision-makers need to take into account to prepare for EIDs.
\end{abstract}

Keywords Mers-CoV $\cdot$ Zika $\cdot$ Migration $\cdot$ Borders

\section{Mers-CoV and Zika Virus}

Mers-CoV and Zika virus have arguably spawned less fear than the viruses analyzed in the previous chapters. Yet their airborne and vector-borne spread, respectively, emphasize further epidemic potential.

A. Bindenagel Šehović, Coordinating Global Health Policy Responses, DOI 10.1007/978-3-319-52006-3_6 
Mers-CoV, Middle East Respiratory Syndrome Coronavirus, ${ }^{1}$ and Zika virus, are the latest two to be added to the pantheon of health security threats. Their emergence reiterates the refrain that the greatest epidemic/pandemic threats are zoonoses. In addition to the existing panoply of fear-inducing consequences of infectious disease spread, Mers-CoV and Zika add effective airborne transmission and debilitating and lethal microcephaly in babies infected in utero, respectively.

In the case of the latter, Zika's impact on infants and their families, and the photographic evidence, recalls the photos of emaciated AIDS orphans. The ensuing visceral local, national and international reactions serve as a catalyst for political action. It is worth noting that Zika is receiving much more global (media) attention than is Mers-CoV, despite the latter's airborne pandemic potential.

\section{Mers-CoV}

Like SARS, Mers-CoV, Middle East Respiratory Syndrome, is a coronavirus, ${ }^{2}$ which infects the upper respiratory tract. It can also cause severe pneumonia and kidney failure. It can be fatal. In marked contrast to $\mathrm{H} 5 \mathrm{Nl}$ and SARS, which are still relatively difficulty to transmit, Mers$\mathrm{CoV}$ is easily spread between people. It is that ability which imparts its epidemic / pandemic potential. ${ }^{3}$

Mers-CoV emerged in Saudi Arabia and was first identified in 2012. Hence its name. Research indicates that Mers-CoV, like SARS, is incubated in bats. Whether it jumped the animal-human barrier via bats, infected dates (which both bats and humans ingest, uncooked), or even via camels remains unclear. "We know that dromedary camels are reservoirs of the MERS coronavirus but we don't know if there are other

${ }^{1}$ See WHO, "Middle East respiratory syndrome coronavirus (Mers-CoV)" (June 2015), available at: http://www.who.int/mediacentre/factsheets/mers-cov/en/.

${ }^{2}$ Ibid.

${ }^{3}$ For visualization see Khan, Kamran, et al. (2013). "Potential for the International Spread of Middle East Respiratory Syndrome in Association with Mass Gatherings in Saudi Arabia," PLOS (July 17); and the image entitled, "CityLevel Destinations of Air Travelers Departing Mers-CoV Source Countries and Origins of Hajj Pilgrims," available at: currents.plos.org. 
animals harboring the virus." 4 According to the WHO, in addition to Saudi Arabia, "strains of MERS-CoV that are identical to human strains have been isolated from camels in several countries, including Egypt, Oman, (and) Qatar." ${ }^{5}$ More research will be needed to confirm if bats are the original source of MERS.

What is clear is that Mers-CoV transmission occurs within confined spaces where the virus can easily pass through the air to the airways of (large) numbers of people. There is a high risk for infection transmission during large movements of people, such as the annual Hajj, which sees some 2-3 million pilgrims enter Saudi Arabia, as well "the 5-6 million pilgrims who journey for Umrah from 180 countries." Another high-risk situation is that in overcrowded hospitals, as seen by numerous transmissions which occurred in South Korea by a traveler thought to have brought the virus into that country. However, as of this date, there has not yet been sustained human-to-human transmission.

Given both the recent identification and prioritization of Mers-CoV, its timeline is correspondingly brief:

\section{Timeline of the Most Important Dates FOR MERs-CoV}

2012: Mers-CoV emerged in Saudi Arabia. Since then, the WHO has recorded 1,690 cases, 603 of which have been fatal. ${ }^{7}$

May 2015: South Korea reported what has been described as a "superspreading" event with dozens of diagnosed Mers-CoV cases after exposure to a single patient.

${ }^{4}$ Maurice, John (2015). "Too Many Unknowns Stymie Response to MERS," The Lancet, Vol. 386, Issue 9988, 15 (July 4).

${ }^{5}$ See WHO, "Middle East respiratory syndrome coronavirus (Mers-CoV)".

${ }^{6}$ Elachola, Habida and Ziad A. Memish. (2016). "Oil Prices, Climate ChangeHealth Challenges in Saudi Arabia," The Lancet, Vol. 387, Issue 10021, 827-829 (January 27).

${ }^{7}$ See WHO, "Middle East respiratory syndrome coronavirus (Mers-CoV)—Saudi Arabia" (March 18, 2016), available at: http://www.who.int/csr/don/l8march-2016-mers-saudi-arabia/en/. 
While more difficult to spread person-to-person than its cousin, SARS, Mers- $\mathrm{CoV}$ is most likely to spread in health care environments. ${ }^{8}$ At this writing, Mers-CoV cases have been reported in a total of 26 countries, the latest of which, Thailand, reported an imported case in January 2016.

As of 3 September 2015: the WHO had held 10 meetings of the International Emergency Committee regarding Mers-CoV.

\section{Initial Responses to Mers-CoV}

Since Mers- $\mathrm{CoV}$ is a newly emerging infectious disease (EID) about which little is known, and while a brief flare-up scored international attention, it has not led to sustained transmission, few resources are being spent on any response to it. The most affected countries, Saudi Arabia and South Korea, appear much more focused on falling oil prices and North Korea's nuclear weapons' tests, elements of economic and military state security, then on health security. The WHO also did not declare the virus to be a Public Health Emergency of International Concern (PHEIC). This means, once again, that the only if any response remains with the affected national states.

As has been the mantra here, the most critical element of anticipating the emergence of zoonoses such as Mers-CoV, is the awareness that one such - or a number of such viruses - can emerge or be imported to any country around the world. Failing to note this risk is an harbinger for just such an occurrence. Testifying to this, Keiji Fukuda, the WHO's Assistant Director-General for Health Security says:

The reality of the world today is high levels of travel and inter-connectedness, so it should be no surprise to see any infection appearing anywhere... But when I visited South Korea in June, it was clear that the health workers there had at first thought of MERS as if it was on the other side of the world, as if it couldn't happen there. ${ }^{\text {? }}$

${ }^{8}$ Gostin, L. O. and D. Lucey. (2015). "Middle East Respiratory Syndrome: A Global Health Challenge." JAMA, vol. 314, Issue 8, 771-772. doi: 10.1007/ 978-3-319-52006-3_5.

${ }^{9}$ Maurice, John (2015). “Too Many Unknowns Stymie Response to MERS.” 
The very notion of a globalized world must take into account the possibility of a global pandemic.

Thus, first among the major factors contributing to the emergence and spread of an infectious disease agent, notably a zoonosis like Mers- $\mathrm{CoV}$, is insufficient awareness about the potential posed by the virus in the first instance. Second, insufficient engagement by all relevant sectors, and third, insufficient implementation of scalable infection control measures, especially in health care settings such as emergency departments, ${ }^{10}$ exacerbates the problem-and the risk of a global pandemic.

Yet these interventions were largely absent in the local and national response to Mers-CoV. The "world" has so far been lucky in that Mers$\mathrm{CoV}$, despite being transmissible between humans, has not be afforded an opportunity to spread far and wide. Luck, however, does not constitute an effective response plan.

National governments need not only to have the knowledge and capacity to implement the recommendations from information gathering to information and response coordination, including with the WHO. They also need to have the assurance of a benefit for their efforts, including not being subject to unnecessary travel advisories or warnings, or economic losses. This raises on the one hand the specter of "brain drain", of professionals migrating out of the country to where their efforts are rewarded by both better conditions and salaries - taking their surveillance expertise elsewhere. On the other hand, it risks the invoking of "viral sovereignty," which reappeared with regard to Mers-CoV: "after Saudi Arabia sent blood samples to Erasmus Medical Center in the Netherlands and Mers-CoV was identified, Erasmus filed for a patent." ${ }^{11}$ Just as in the Indonesian case, this means that Erasmus can sell the patent to a pharmaceutical company to develop and market vaccines or treatments against Mers-CoV, which it could then sell-back-to Saudi Arabia. "Saudi Arabia says that action violates national rules and that Erasmus acted unethically." 12

${ }^{10}$ See "WHO Statement on the 10th Meeting of the IHR Emergency Committee regarding MERCS (3 September 2015)," available at: http://www.who.int/med iacentre/news/statements/2015/ihr-emergency-committee-mers/en/.

${ }^{11}$ Gostin and Lucey. "Middle East Respiratory Syndrome: A Global Health Challenge."

${ }^{12}$ Ibid. 
Further components of a more effective response are discussed in Chapters 7 and 8 .

\section{ZIKA VIRUS}

Zika virus has long been endemic in Eastern Africa. It is caused by a virus of the Flaviviridae family, and was first isolated in 1947 from a monkey in Uganda's Zika forest, ${ }^{13}$ to which it owes its name. Also a zoonosis, as is each of the emerging infectious diseases discussed here, Zika antibodies have been found in animals including orangutans, zebras, elephants, water buffalo and rodents. ${ }^{14}$ It is transmitted when a mosquito bites an infected person, and then another, and so on, transferring the virus as it feeds, as is also the case with malaria transmission. More rarely, it appears that Zika can also, like HIV and Ebola, be transmitted via sexual intercourse and possibly blood transfusions. Despite its association with Africa in the media (as are also HIV and Ebola), there are actually two Zika lineages: the African and the Asian, the latter of which has recently emerged in the Pacific and the Americas, where it is currently spreading in epidemic and pandemic proportions.

The virus's endemic presence in East Africa means that a high proportion of East Africans are infected as children and develop resistance to the virus, rendering them-it is thought-immune to its more severe effects. In other words, once infected, children develop antibodies to fight a recurrent infection. This would possibly shield women when pregnant from passing the virus from an infected mosquito onto their fetus. Such immunity is not found in much of the rest of the world, meaning those yet unexposed to Zika are vulnerable.

The general course of Zika infection appears to be asymptomatic, with a limited number of cases presenting fever, conjunctivitis and muscle fatigue. Even when the signs and symptoms appear during the incubation period of 3-12 days they usually abate within a further 4-7 days. ${ }^{15}$ Yet in some cases, infection with Zika virus appears to be related to an unusually high number of those infected displaying

${ }^{13}$ See "European Centre for Disease Prevention and Control Factsheet for Health Professionals," available at: http://ecdc.europa.eu/en/healthtopics/zika_virus_infec tion/factsheet-health-professionals/Pages/factsheet_health_professionals.aspx.

${ }^{14}$ Ibid.

${ }^{15}$ Ibid. 
symptoms of Guillain-Barré Syndrome (GBS). This is an autoimmune disorder which can result in dangerous muscle weakness or paralysis. It can lead, for example, to an inability of the central nervous system to regulate breathing.

More worrying is the recently collected evidence linking Zika infection during pregnancy to microcephaly in the fetus. This means that the virus crosses the placental barrier and is transmitted to the amniotic fluid and the developing fetus itself. Microcephaly is a condition in which a disproportionately high number babies born of mothers infected during pregnancy display extremely small heads and brains, with a high degree of malformation, malfunction and disability. The high number of babies being born with microcephaly was the trigger that caught the world's attention.

The Zika-carrying mosquitos are mostly those of the Aedes species, which are deemed "tropical" mosquitos, Ae. aegypti, and, most efficiently, Ae. albopictus. ${ }^{17}$ These are expanding their territories throughout warming and wetter climates: the more "tropical" the globe becomes, the greater the area in which these tropical Aedes mosquitos will thrive. Indeed, the current pandemic is thought to have traveled, via mosquito, from French Polynesia to Easter Island to Brazil and Central America. It is currently making its way from the southern hemisphere into the warming north: into northern Europe and the southern United States-and beyond. If and when additional mosquito species become vectors for Zika virus, it is likely to spread further. $^{18}$

Additional potential carrier mosquito species include Ae. africanus, Ae. albopictus, Ae. polynesiensis, Ae. unilineatus, Ae. vittatus and Ae. hensilli). ${ }^{19}$ As early as 2011 , the Ae. Albopictus species was not only present,

${ }^{16}$ See "Mayo Clinic Diseases and Conditions, Guillain-Barre syndrome," available at: http://www.mayoclinic.org/diseases-conditions/guillain-barre-syndrome/ basics/symptoms/con-20025832.

${ }^{17}$ See "USCDC Transmission \& Risks Through Mosquito Bites," available at: http://www.cdc.gov/zika/transmission/index.html.

${ }^{18}$ Risk map for spread of Zika virus, in Gardner, Lauren M., Nan Chen and Sahotra Sarkar. (2016). "Global Risk of Zika Virus Depends Critically on Vector Status of Aedes albopictus," The Lancet, Vol. 16, Issue 5, 522-523 (May).

${ }^{19}$ See "European Centre for Disease Prevention and Control Factsheet for Health Professionals." 
but widespread, in south-western Germany. ${ }^{20}$ Its arrival evidences the potential for Zika to spread there, too.

\section{Timeline of the Most Important Dates for Zika Virus}

1947: Zika virus isolated from a monkey in Zika forest, Uganda.

1948: The Zika virus vector identified as Aedes africanus, also found in the Zika forest. ${ }^{21}$

1952: The first human Zika infection identified in Nigeria.

It is worth noting that HIV, Ebola and Zika all emerged in the middle of the twentieth century. That each of these zoonoses jumped the animalhuman barrier at roughly the same time speaks to a number of things:

First, the encroachment of human beings upon natural habits of the viral vectors, primarily those of chimpanzees, bats or rodents.

Second, the primary density and secondary connectedness of human settlements, which enabled the viruses to develop transmissibility and then to spread-sometimes rapidly up and down rivers and roads, and then by air(travel). Viral movement via people is now being enabled by the fanning out of mosquito populations around the globe as well: an (asymptomatic) person infected with Zika can now board a plane in Uganda and land in Berlin, which is no longer too cold to host Aedes mosquitos. Awaiting Aedes then proceed to further transmit the virus. This scenario is only slightly hypothetical—and could become reality at any time.

Third, human technology is better able to identify and to trace the origins of such zoonoses. In order to respond to them, we will have to not only determine origins and presence, but also provide insights into the possible responses.

${ }^{20}$ Werner, D., M. Kronefeld, F. Schaffner, H. Kampen. (2012). "Two Invasive Mosquito Species, Aedes Albopictus, and Ades Japonicus Japonicus, Trapped in South-West Germany, July to August 2011," Eurosurveillance, Vol. 17, Issue 4 (26 January).

${ }^{21}$ See "European Centre for Disease Prevention and Control Factsheet for Health Professionals." 
2007: A Zika outbreak was reported on Yap Island, Federated States of Micronesia, from April to July. This was the first outbreak identified outside of Africa. ${ }^{22}$

2013-2015: Several significant outbreaks were notified on islands and archipelagos in the Pacific, including a large outbreak in French Polynesia. ${ }^{23}$ 2014: In retrospect, a new study published in the Journal of Neglected Tropical Diseases, recorded the presence of Zika virus in Haiti since 2014 or even $2013 .^{24}$

2015: Zika emerged in South America, notably in Brazil. With the Brazilian outbreak, Zika has become officially considered to be an emerging infectious disease (EID).

February 1, 2016: The WHO declared Zika virus to be a PHEIC.

March 3, 2016: WHO launched its response framework for Zika.

March 8, 2016: The WHO Emergency Committee underscored the nature of the Zika outbreak as a PHEIC.

March 18, 2016: Germany's Ministry of Health approved a new reporting requirement for Zika.

June 1, 2016: The United States had 618 reported cases in the states and DC and 1,114 in US Territories, according to ArboNET. ${ }^{25}$

\section{Responding to Zika in Real Time}

Given that the Zika pandemic is unfolding in real time, it is only possible to describe and briefly assess the attributes of the ongoing responses here. Internationally, by declaring the spread of Zika, particularly in the Americas, to be a PHEIC, the WHO has taken the lead in the response

${ }^{22}$ Ibid.

${ }^{23}$ Ibid.

${ }^{24}$ See Lednicky, John et al. (2016). "Zika Virus Outbreak in Haiti in 2014: Molecular and Clinical Data," PLOS (25 April 2016), available at: http://jour nals.plos.org/plosntds/article?id=10.1371\%2Fjournal.pntd.0004687.

${ }^{25}$ National surveillance system for arboviral diseases in the United States, managed by the CDC and state health departments. 
to the virus. In addition to requesting surveillance and supporting research efforts to confirm the link between Zika infection and microcephaly, the WHO has also issued recommendations in response. The WHO response framework launched on March 3, 2016, takes these into account. ${ }^{26}$

Its main focus is the neonatal malformations attributed to Zika infection.

The WHO states explicitly, however, that "there should be no restrictions on travel or trade with countries, areas and/or territories with Zika virus transmission." In contrast, both Germany, and the United States explicitly recommend that pregnant women, or women wishing to become pregnant, desist from traveling to areas with an ongoing Zika virus outbreak.

While such recommendations try to walk the lines between awareness of a threat, advocacy for risk avoidance and alarmism, the difference is a fine one. As such, public health emergency declarations-by the WHO or individual states-can focus political attention and lead to a surge in financial resource flows towards response, or they can increase the (abuse) of authority during a public health emergency. For example, Brazil, proactively declared a public health emergency with regard to Zika in November 2015. ${ }^{27}$ If and when the expanded political (and military; more on this danger below) powers granted under the emergency are not revoked, these could lead to serious infringement of biological and civil liberties, particularly as these reach far beyond the external stop-gap military interventions proferred in response to the West African Ebola outbreak (see chapter four).

\section{GERMANY}

In that vein, Germany's Ministry of Health approved a new infectious disease protection law (IfSG) compliance measure on March 18, 2016. ${ }^{28}$ It included a new reporting requirement for arboviruses, of which Zika is

${ }^{26}$ See WHO “Emergencies: Zika Virus Outbreak Global Response” (17 June 2016), available at: http://www.who.int/emergencies/zika-virus/response/en/.

${ }^{27}$ Gostin and Lucey. "The Emerging Zika Pandemic: Enhancing Preparedness."

${ }^{28}$ See German Ministry of Health. Original: "Bundesministerium für Gesundheit, Informationen zum Zika-Virus" (12 May 2016), available at: http://www.bmg. bund.de/ministerium/meldungen/2016/Zika-Virus-280116.html. 
one, and came into effect in May 2016. As Federal Minister of Health, Hermann Gröhe, noted:

Experts doubt the spread of Zika infection in Germany, but we remain vigilant. With the new reporting requirement for arboviruses, Germany is preemptively preparing extra surveillance with regard to possible Zika infection in returning travelers. By doing so, local German health agencies hope to gain time in launching a responsive intervention in the event one is necessary. ${ }^{29}$

His statement coincided with the Foreign Ministry issuing a travel advisory against pregnant women or women planning to become pregnant from visiting countries experiencing a Zika outbreak.

\section{UNited STATES}

The US Centers for Disease Control (USCDC) operated initially under the assumption that Zika infection during pregnancy was a cause of microcephaly and started tracking cases. The link between Zika infection and microcephaly, as well as a host of other serious health effects, has since been established.

Zika virus can be passed from a pregnant woman to her fetus, and infection during pregnancy can cause a serious birth defect of the brain called microcephaly and other severe brain defects. Other problems have been detected among fetuses and infants infected with Zika virus before birth, such as defects of the eye, hearing deficits, and impaired growth. ${ }^{30}$

Like the German government, the CDC even goes as far-further than the $\mathrm{WHO}$ - as to recommend that pregnant women avoid travel to regions experiencing Zika epidemics. "CDC recommends special precautions for

${ }^{29}$ Ibid. Author's translation. Original: "Eine Übertragung in Deutschland halten die Experten für sehr unwahrscheinlich, aber wir bleiben wachsam. Mit der Meldepflicht für Arboviren sorgen wir außerdem dafür, dass etwa eine Zika-Infektion bei Reiserückkehrern in Deutschland besser überwacht werden kann. Damit gewinnen die Gesundheitsämter vor Ort wertvolle Zeit zum schnellen Handeln.”

${ }^{30}$ See USCDC, "For Pregnant Women," available at: http://www.cdc.gov/zika/ pregnancy/index.html. 
pregnant women. Women who are pregnant should not travel to areas with Zika." 31

This contradictory advice- between the WHO and the governments of Germany and the United States-contravenes the spirit of the IHRs. It also makes it clear that national security overrides shared international concerns. Finally, it also demonstrates the lack of 'teeth' in the recommendations of both the WHO and the IHRs, versus those requirements imposed by states.

National politicking further reveals this imbalance: "This is an emergency," said Josh Earnest, the White House press secretary. "The American people are counting on Congress to act." 32 However, while the Obama Administration requested US\$1.9billion "in emergency financing to combat the Zika virus in February," it was confronted with Republican counterproposals only to "redirect \$510 million previously allocated to fight Ebola-a move that was made this month." 33 This bickering reveals more than partisan (in)fighting.

\section{IMPLICATIONS AND CONCLUSIONS}

The contestation over prioritization of problems and of (policy) responses illustrates that states-governments-are and remain the main arena within which the identification of a threat, the decision to respond and the nature and scope of such a response are hammered out. First, states, through governmental organizations, institutes, non-state actors (NSAs), NGOs, charities and even social media platforms, are the site and source of initial outbreak information. Second, they are the entity responsible for notifying the WHO. Third, they are the legitimating participants of the WHO's central coordinating function: states make up the World Health Assembly, ${ }^{34}$ and the Executive Board, ${ }^{35}$ the constitutive body which

\section{${ }^{31}$ Ibid.}

${ }^{32}$ Herszenhorn, David M. (2016). "Senate Nears Deal for at Least \$1.1 Billion to Fight Zika Virus," New York Times (April 27), available at: http://www.nytimes. com/2016/04/27/us/politics/zika-virus-senate-emergency-funding.html. ${ }^{33}$ Ibid.

${ }^{34}$ Composed of all member states of the UN.

${ }^{35}$ The Executive Board is composed of 34 persons who are technically qualified in the field of health, each designated by a member state that has been elected to serve by the World Health Assembly. Member states are elected for three-year terms. See 
oversees its own decision-making. Fourth, states are the sites of any intervention; and as sovereign states they decide up who, what, where, when, and how such an intervention might take place - or not (see Ebola in Liberia, Chapter 4, for instance). Fifth, and finally, states are ultimately responsible for the implementation and outcome of any and all decisions pertaining to epidemic response because they are the final arbiter of security, including health security, within their territory.

Given these formidable responsibilities allocated the state, its-statesecurity generally takes precedence legally and practically (financially) over other forms. Historically, from roughly the establishment of the modern state system beginning around 1648 with the treaties of Westphalia through today, state security has been conceived of as territorial control within inviolable borders. This state security also invokes, to varying degrees, the protection of the human (citizen) population within that territory. It can, and has been, argued that the state's right to exist trumps that of citizens' rights to (more than) physical protection. Without the state apparatus and its enactment of its allocated responsibilities, little protection exists for citizens at all.

While the champions of securitization hold fast to this interpretation of the state, it arguably points instead to the urgent need to reorder the relationship between states-citizens /states-territories /states-nonstate actors. This will be explored in more detail in the final two chapters.

Chapter 7 looks at how states, in cooperation with others, make such decisions. It will look at what factors play a role in their decision-making, and how it might be necessary and possible to shift or share the responsibilities that they currently bear. This rethinking is especially vital in light of the increasing number of existing and anticipated EIDs.

WHO, "Governance: Executive Board Members," available at: http://www.who. int/governance/eb/eb_members/en/. 